\title{
In vitro Propagation of Oreocallis grandiflora (Lam.) R. Br., A Medicinal Threatened Plant
}

\author{
Percy Olivera-Gonzales ${ }^{1}$, Edson M. Yldefonzo ${ }^{2}$, Elder M. Mestanza ${ }^{2}$ \\ and Carmen Tamariz-Angeles ${ }^{{ }^{*}}$
}

${ }^{1}$ Laboratorio de Biología, Facultad de Ciencias, Universidad Nacional Santiago Antúnez de Mayolo, Av. Centenario 200, 02002 Independencia, Huaraz, Ancash, Perú. ${ }^{2}$ Facultad de Ciencias Agrarias, Universidad Nacional Santiago Antúnez de Mayolo, Av. Centenario 200, 02002 Independencia, Huaraz, Ancash, Perú.

Authors' contributions

This work was carried out in collaboration between all authors. Authors POG and CTA conceived and designed the study. Authors EMY and EMM executed and performed the experimental work. Author $P O G$ wrote the first draft of the manuscript. Author CTA reviewed the first manuscript and wrote the final manuscript. All authors read the draft and gave consent for its publication.

Article Information

DOI: $10.9734 / A R R B / 2017 / 34724$ Editor(s):

(1) Wafaa Mohamed Shukry, Departement of Botany, Faculty of Science, Mansoura University, Mansoura, Egypt.

(2) George Perry, University of Texas at San Antonio, USA.

Reviewers:

(1) Aneta Gerszberg, University of Lodz, Poland. (2) Dariusz Kulus, UTP University of Science and Technology, Poland. (3) Federico A. Gutiérrez-Miceli, Instituto Tecnológico de Tuxtla Gutiérrez Chiapas, México. (4) K. Kalimuthu, Bharathiar University, Tamil Nadu, India. Complete Peer review History: http://www.sciencedomain.org/review-history/19936

Original Research Article

Received $8^{\text {th }}$ June 2017

Accepted $5^{\text {th }}$ July 2017

Published $8^{\text {th }}$ July 2017

\section{ABSTRACT}

Aims: To promote the conservation and biotechnology approach of Oreocallis grandiflora, a promising wild, medicinal and agroforestry Peruvian plant, a methodology for its in vitro propagation was performed.

Study Design: Disinfection and germination of seed, followed by shoot multiplication and rooting using in vitro techniques.

Place and Duration of Study: Follicles were collected in Yupa - Huaraz (930'26.76"S, 7728 '21.33"W) and the experimental procedure was do ne between January 2013 and December 2016.

Methodology: Follicles with different colors were disinfected with ethanol $70 \%$ at different times, 
and seeds were place on basic culture medium composed by 1/2 Murashige and Skoog, sucrose (30 $\left.\mathrm{g} \cdot \mathrm{L}^{-1}\right)$ and phytagel $\left(3 \mathrm{~g} \cdot \mathrm{L}^{-1}\right)$, at $\mathrm{pH}$ 5.7. Shoot induction was performed using $N^{6}$-benzylaminopurine (BAP) at $0.5,1,2,3$ and $4 \mathrm{mg} \cdot \mathrm{L}^{-1}$. For root induction, $\alpha$-naphthalenacetic acid (NAA) or gibberellic acid $\left(\mathrm{GA}_{3}\right)$ at $0.25,0.50,0.75$ and $1.0 \mathrm{mg} \cdot \mathrm{L}^{-1}$ were used.

Results: Disinfection of follicles at 15 and $20 \mathrm{~min}$. of $70 \%$ ethanol were successful at $100 \%$, and all seed germinated without addition of any growth regulator. The best shoot induction treatments were 3.0 and $4.0 \mathrm{mg} \cdot \mathrm{L}^{-1}$ of BAP at 60 days of PGR exposition. For the root development PGR supplement was not necessary, but $\mathrm{GA}_{3}$ improved rooting percentage and explants growth while NAA induced callusing.

Conclusion: This is the first report of in vitro propagation of $O$. grandiflora, and provides important results to promote its domestication, ex situ conservation, and biotechnological applications.

Keywords: $\alpha$-naphthalenacetic acid; gibberellic acid; $N^{6}$-benzylaminopurine; Oreocallis grandiflora; Peruvian plant; Proteaceae.

\section{INTRODUCTION}

Oreocallis grandiflora (Lam.) R. Br. is a shrub known as "chacpá", "cucharilla", "Ilama llama", "saltaperico", or "atash". It grows between 15004000 m.a.s.l. in the Peruvian Andean valleys from Cusco to San Martin [1,2,3], but there are also reports of populations in southern Ecuador [4]. It is used as hedgerows, and its wood is used as firewood and basketry [3]. In traditional medicine, its cooked leaves are used for ulcers, and the infusion for uterus ailments and colds $[1,3,4]$; the decoction of its flowers is used for vaginal bleeding, ovary and uterus inflammation [5]. Decoction of its stems is drunk for liver problems, and the whole plant is mixed with other plants to be used in baths for cold [6]. Pharmacological studies have shown that ethanolic extract from its leaves have hypoglycemic activity by inhibiting a-amylase and $\beta$-glucosidase, also show antioxidant activity, with $\mathrm{IC}_{50}$ of $15 \mu \mathrm{g} \cdot \mathrm{mL}^{-1}$ compared to $5 \mu \mathrm{g} \cdot \mathrm{mL}^{-1}$ of a-tocopherol, providing evidence that $O$. grandiflora is a promising plant for the treatment of diabetes [7]. In spite of the ethnobotanical usefulness of $O$. grandiflora, in Peru, this species is endangered due to irrational use and absence of initiatives for its propagation [1], this problem is worsened by agricultural and forestry expansion with exotic species, that reduces the possibilities of regeneration and conservation in its natural habitats. Besides, $O$. grandiflora shows a poor capacity of vegetative propagation when live stakes are used [1]. Reynel and Marcello [2] mention that its seeds have high percentage of germination on soil with mycorrhizal fungi and greenhouse conditions, but also these seeds can be eaten by rodents. None reports about its pathogens was found, but some $O$. grandiflora plants, in its natural habit, show thin dark layer on leaves and stems similarly to smut fungi which seems to be a pathogen of this species.

On the other hand, the use of biotechnology through plant micropropagation techniques allows the rapid production of plants at low cost, and in limited spaces [8]. These techniques are based on somatic cell culture, or tissue and organs culture under controlled conditions, to produce a high number of plantlets free of microorganisms, and in short times compared with the conventional propagation $[9,10]$. Thus, micropropagation is becoming an alternative for multiplication and preservation of endangered species, especially wild medicinal plants; and it can get high quality seedlings free for viral, fungal and bacterial pathogen [8].

According to these considerations, the in vitro tissue culture of $O$. grandiflora was conducted in order to propose an alternative for its preservation. In this sense, hypocotyls of $O$. grandiflora were evaluated about their ability to multiply by shoots, and rooting process using common plant growth regulators (PGRs) and PGR-free culture medium.

\section{MATERIALS AND METHODS}

\subsection{Plant Material and Disinfection of Follicles}

Follicles were collected in Yupa - Huaraz (930'26.76" S, 7728'21.33" W, 3554 m.a.s.I.).

They were transported in sterile bags, and stored at $4^{\circ} \mathrm{C}$ for about five days. Branches with flowers were deposited in the David Smith Herbarium UNASAM (Fig. 4A).

The basic medium used in all micropropagation stages was $1 / 2$ Murashige and Skoog (MS1/2) 
supplemented with $30 \mathrm{~g} \cdot \mathrm{L}^{-1}$ sucrose and $3 \mathrm{~g} \cdot \mathrm{L}^{-1}$ phytagel, and with $\mathrm{pH}$ adjusted to 5.7. The environmental conditions were darkness at $24 \pm$ $2^{\circ} \mathrm{C}$ for seed germination; while for establishment, shooting and rooting, the seedlings were grown using a photoperiod of 16 hours of light at 22.4 photons, and temperature of $20 \pm 2^{\circ} \mathrm{C}$.

To perform the disinfection of $O$. grandiflora seeds; red follicles, completely closed, healthy and undamaged were immersed in $70 \%$ ethanol at $0,5,10,15$ and 20 minutes. For each treatment 10 follicles were used, each one was considered as a replicate. These treated follicles were opened with a sterile small saw; and 10 seeds per follicle were grown on basic medium in polycarbonate Magenta (V8505 - Magenta ${ }^{\mathrm{TM}}$ vessel, Sigma). Disinfection efficiencies [\%] were evaluated after 7 days. Ten treated seeds of each disinfected follicle were considered $100 \%$.

\subsection{In vitro Germination and Seedling Establishment}

To evaluate germination success, five stages of seed maturation were considered based on follicle color: green, yellow, reddish-yellow, red, and brown (Fig. 4B). These were obtained following the best disinfection treatment identified in the previous step. Ten follicles per stage were used, and 10 seeds of each follicle were grown on the basic medium in polycarbonate Magenta. Germination percentage was evaluated at 15 days. The total number of seeds by follicle was considered 100\%. Germinated seedlings followed growing for 35 more days to complete their in vitro establishment.

\subsection{In vitro Shoot Multiplication}

Under sterile conditions, seedlings were cut at their stem base to obtain hypocotyls of $3.0 \mathrm{~cm}$ long, they were transferred to $55 \mathrm{~mL}$ glass culture tubes, with $10 \mathrm{~mL}$ of basic medium supplemented with $0.5,1,2,3$ and $4 \mathrm{mg} \cdot \mathrm{L}^{-1}$ BAP (Sigma, B3408), and control without BAP. The samples were grown under conditions described in section 2.1. All treatments were evaluated using 2 groups, and each group had 10 hypocotyls. The percentage of shooting, and number of shoots per explant were evaluated at $15,30,45$ and 60 days.

\subsection{In vitro Rooting}

Before rooting, shoots - containing their apical bud - from the multiplication step were transferred to PGR-free culture medium to grow for 30 days. Shoots of similar size and thickness were selected and transferred to basic medium, with PGR supplement. NAA (Sigma, N0640) or $\mathrm{GA}_{3}$ (Sigma, G7645) were used separately as PGR supplements at $0.25,0.50,0.75$ and 1.0 $\mathrm{mg} \cdot \mathrm{L}^{-1}$. Control without PGR supplement was also used. All treatments had two groups, each group had 10 shoots. Culture conditions are described in section 2.1. The parameters evaluated were: roots and callus percentage, number of roots per plantlet, main root length, and the aerial plant part length (stem with leaves) at 30,60 and 90 days.

\subsection{Statistical Analysis}

The statistical design used to evaluate the percentage of disinfection and germination was the Completely Randomized Block Design (CRBD) using ten follicles (blocks) with ten seeds (replicates) for each one. The CRBD was also used to evaluate shooting, rooting and callusing; where they were design using two blocks with ten replicates each one. Number of shoots, number of roots, length of the main roots, and length of aerial part of the explants were evaluated using the Completely Randomized Design (CRD), and for which it was considered only the samples that showed positive effect represented in the percentage of shooting or rooting. Averages and standard deviations were calculated, ANOVA and the Duncan's test ( $P$ $<0.05)$ were used for mean comparison in all cases.

\section{RESULTS AND DISCUSSION}

\subsection{Plant Material, Disinfection of Follicles, Germination, and Explant In vitro Establishment}

Although the mature follicles of $O$. grandiflora are deshiscent, immature follicles were used to ensure that the seeds would be mostly aseptic, requiring only follicle surface disinfection. Disinfection at $100 \%$ was reached at 15 and 20 minutes exposure to $70 \%$ ethanol (Fig. 1A), which shows that its contaminant microorganisms are sensitive to ethanol. In comparison, Lema-Rumińska and Kulus [11] obtained an $83.3 \%$ disinfection efficiency of Astrophytum asterias seeds after treating them with $70 \%$ ethanol and $1.58 \% \mathrm{NaOCl}$ for 15 minutes.

Seed germination is an important process in the plant life cycle and it is influenced by 
environmental and physiological dormancy factors [12]. O. grandiflora has shown that the breaking of dormancy in its seeds did not have special requirements; furthermore, these had $100 \%$ germination without the stimulus of exogenous plant growth regulators supplied (Fig. 1B). In comparison with $A$. asterias a $70 \%$ germination rate on the same medium was recorded [11]. Also, normal growth was observed without exogenous plant growth regulators supplied in the in vitro establishment process. This features described before could be advantageous for $O$. grandiflora seeds, because that allows disinfected seeds to germinate and establish without PGR supplements or other special conditions.

\subsection{In vitro Shoot Multiplication}

No shooting process was observed on basic PGRs-free medium; however, a positive response was observed with BAP-supplemented in medium, which is an important cytokinin of low cost used in many biotechnological procedures because it stimulates cell division, affecting all stages of plant development and growth [13]. The development of axillar shoot needs to break the apical dominance which is controlled by auxin [14]; this breaking could be attained with the addition of cytokinin, because cytokinin

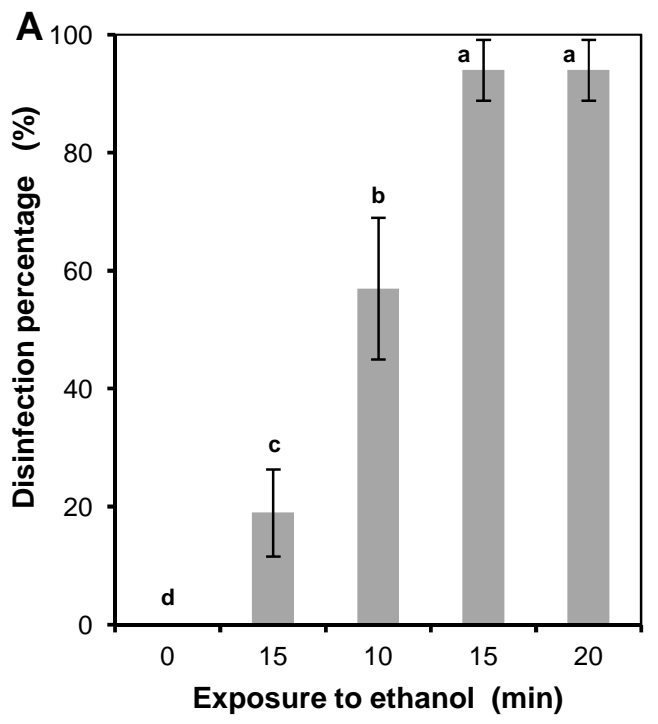

influences the distribution of auxin within the plant, also regulates the sensitivity to auxin via regulation of the Aux/IAA protein SHY2 [15], also Wang et al. [16] have found that cytokinin signaling precedes WUS expression in leaf axils, and activates WUS expression de novo in the leaf axil to promote axillary meristem initiation. But also, it has been described others molecular and biochemical mechanisms of diverse functions in regulating developmental and physiological processes that respond to cytokinin $[15,17,18]$.

Since shoot formation is controlled mainly by cytokinin $[9,10,15,16]$, and cytokinin is critical for cell division and shoot formation during in vitro plant regeneration [15]; shoot multiplication of $O$. grandiflora was assayed using BAP, a cytokinin initially produced synthetically but also occur at low levels naturally in some species [15]. Accordingly, it was found that shoot formation and number of shoots per explant had a direct relation with the concentration of BAP, where it was obtained up to $100 \%$ shooting in treatments with 2,3 and $4 \mathrm{mg} \cdot \mathrm{L}^{-1}$ BAP at 15 days of $P G R$ exposition (Fig. 2A). Likewise, the highest number of shoots was achieved using 3 and 4 $\mathrm{mg} \cdot \mathrm{L}^{-1} \mathrm{BAP}$ at 60 days with an average around 9 shoots per explants (Figs. 2B and 4C).

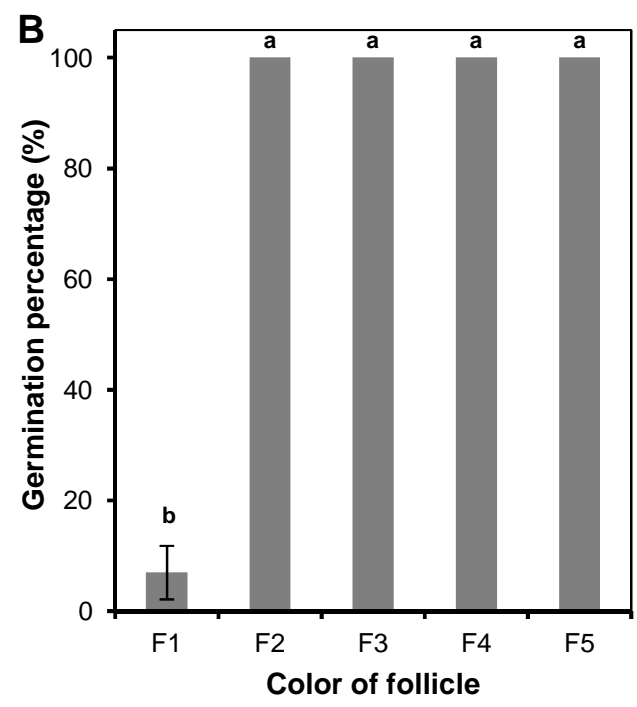

Fig. 1. Follicle disinfection and seed germination of Oreocallis grandiflora. A. Disinfection percentage with $70 \%$ ethanol at $0,5,10,15$, and 20 min.; B. Germination percentage of seed in different maturation stage based on follicle color: green (F1), yellow (F2), reddish-yellow (F3), red (F4) and brown (F5)

Values represent means of 10 block with 10 replicates each one $\pm S D$; and letters indicate the groups with significant differences according Duncan's statistical test $(P<0.05)$ 
Similar results have been reported in some shrubs and trees, for example Feronia limonia produced 11.3 shoot per explant using 1.13 $\mathrm{mg} \cdot \mathrm{L}^{-1}$ BAP [19]. Anona squamosa hypocotyls produced up to 23 shoot per explant with $5 \mathrm{mg} \cdot \mathrm{L}$ BAP [20]; Morus alba var. shidareguwa showed the best shoot multiplication treatment using 1.0 $\mathrm{mg} \cdot \mathrm{L}^{-1}$ BAP at 30 days [8]. The new shoots were cultured on PGR-free after 30 days, and did not show alterations in their leaf and stem morphology rather they had similar feature to $O$. grandiflora plants in their natural environment.

\subsection{In vitro Rooting}

Auxin plays an important role in the rooting process [21], but this complex process dependent of the interaction of auxin-cytokinin $[22,23]$. Molecular studies show that auxincytokinin interaction controls the root meristem development, mutually regulate their pathways and metabolisms controlling the cell division and cell differentiation of the root meristem [22]. Beside, auxins are used in tissue culture to induce callus formation, Kareem et al. [23], in their review of the molecular and biochemical mechanisms and pathways during de novo plant regeneration, mention that auxin play an

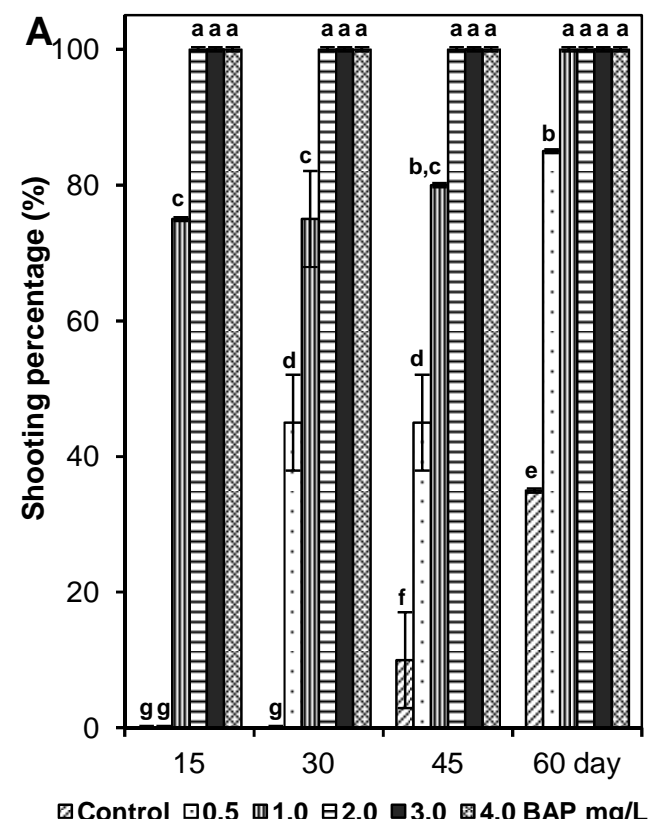

important role activating the development of callus, and organogenesis of root from callus.

In this sense, NAA is an artificial auxin which is used in many cases as rooting inducer, for example in Feronia limonia, $0.19 \mathrm{mg} \cdot \mathrm{L}^{-1} \mathrm{NAA}$ induced $83 \%$ of rooting [19]. Then, the effect of NAA on rooting of $O$. grandiflora was evaluated. It was found that NAA at different doses $(0.25$, $0.50, \quad 0.75$ and $1.0 \mathrm{mg} \cdot \mathrm{L}^{-1}$ ) have induced callusing in shoots of $O$. grandiflora, followed by wilting and death of shoots up to 60 days (Table 1, and Fig. 4E). Kareem et al. [23] refer that the presence of callus is an effect of auxin rich culture medium; further, the formation of callus at the base of the shoots of $O$. grandiflora would be in concordance with some results reported for others woody species treated with NAA at 0.2 to $3 \mathrm{mg} \cdot \mathrm{L}^{-1}[20,24]$. The wilting and death of shoots were reported by Olmos et al. [25], who explained that the callus around the cutting area of shoot disrupts the vascular connections, affecting water and nutrient assimilation. Furthermore, Porfírio et al. [21] in the review of adventitious root formation of Olea europaea mention that the auxin accumulated in the cutting shoots difficult rooting, suggesting that the presence of auxin required for rooting induction

Fig. 2. In vitro shooting of Oreocallis grandiflora using BAP. A. Shooting percentage; and B. Number of shoots per explant

Values of $2 A$ represent means of two blocks $\pm S D$ (each block had 10 hypocotyls); and values of $2 B$ represents means of replicates with shoots $\pm S D$. Letters indicate the groups with significant differences according Duncan's statistical test $(P<0.05)$ 
Table 1. Effects of NAA on Oreocallis grandiflora morphogenesis during rooting stage

\begin{tabular}{|c|c|c|c|c|c|c|}
\hline \multirow[t]{2}{*}{ Parameters } & \multirow{2}{*}{$\begin{array}{l}\text { Exposure } \\
\text { (days) }\end{array}$} & \multicolumn{5}{|c|}{ NAA $\left(\mathbf{m g} \cdot \mathrm{L}^{-1}\right)$} \\
\hline & & Control & 0.25 & 0.50 & 0.75 & 1.0 \\
\hline \multirow[t]{3}{*}{ Callusing (\%) } & 30 & 0.0 & $65.0 \pm 7.1$ & $80.0 \pm 0.0$ & $100 \pm 0.0$ & $100 \pm 0.0$ \\
\hline & 60 & 0.0 & $95.0 \pm 7.1$ & $100 \pm 0.0$ & $100 \pm 0.0$ & $100 \pm 0.0$ \\
\hline & 90 & 0.0 & $100 \pm 0.0$ & $100 \pm 0.0$ & $100 \pm 0.0$ & $100 \pm 0.0$ \\
\hline \multirow[t]{3}{*}{ Rooting (\%) } & 30 & $30.0 \pm 0.0$ & 0.0 & 0.0 & 0.0 & 0.0 \\
\hline & 60 & $40.0 \pm 0.0$ & 0.0 & 0.0 & 0.0 & 0.0 \\
\hline & 90 & $45.0 \pm 7.1$ & 0.0 & 0.0 & 0.0 & 0.0 \\
\hline Aerial plant length \pm & 30 & $28.9 \pm 1.9$ & $31.3 \pm 3.2$ & $31,6 \pm 2.4$ & $27.9 \pm 2.1$ & $26.8 \pm 2.5$ \\
\hline $\mathrm{SD}(\mathrm{mm})$ & 60 & $33.5 \pm 2.7$ & $32.0 \pm 3.7$ & $30,3 \pm 2.5$ & $26.4 \pm 2.3$ & $23.6 \pm 2.6$ \\
\hline
\end{tabular}

Percentages of callusing and rooting are means of two blocks with 10 samples each one \pm SD. Values of aerial plant length are means of 20 replicates $\pm S D$. * , the plants died
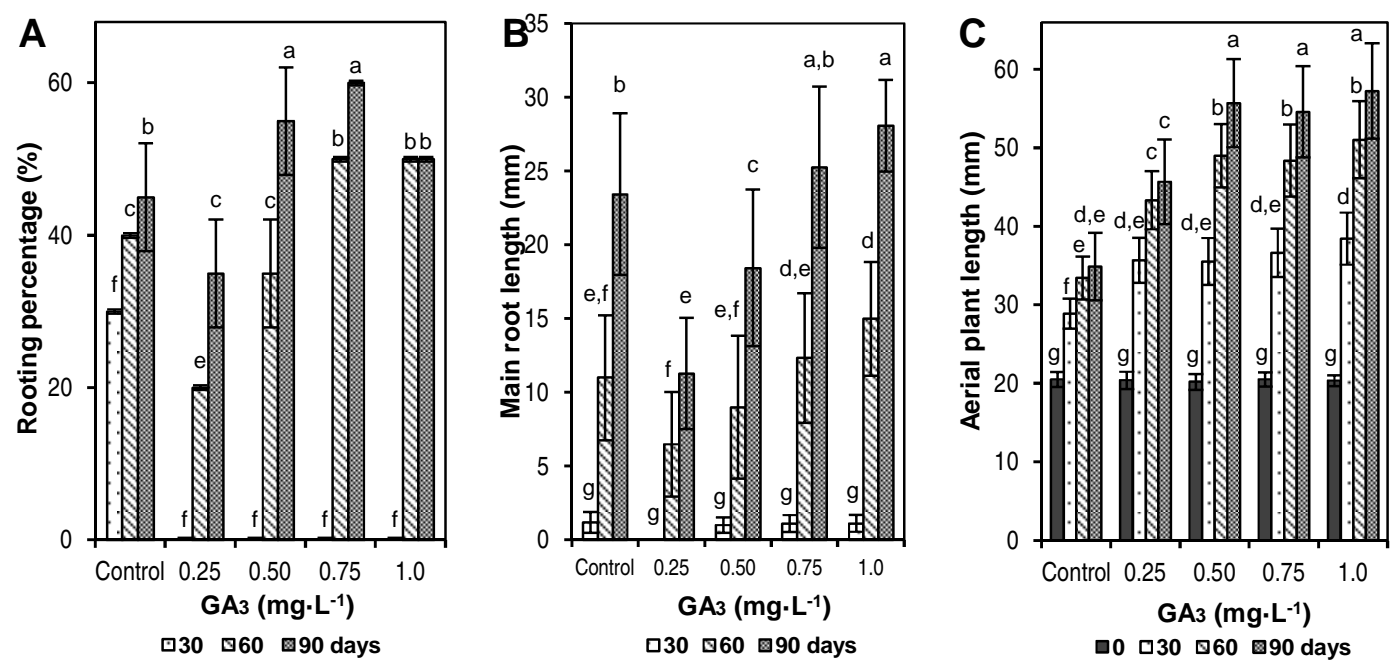

Fig. 3. In vitro rooting of Oreocallis grandiflora using gibberellic acid $\left(\mathrm{GA}_{3}\right)$. A. Rooting percentages; B. Main root length; and C. Aerial plant length (stem with leaf)

Values represent means of two blocks with 10 samples $\pm S D(3 A)$; and means of samples that had roots \pm $S D(3 B, 3 C)$. Letters indicate the groups with significant differences according Duncan's statistical test $(P<0.05)$

would have an opposite effect upon rooting expression. For this reason, some rooting methodologies include two steps: rooting induction with short times of NAA, followed by rooting expression on culture medium without NAA $[9,21]$.

Aroonpong and Chang [8] also found that auxins were unnecessary for in vitro rooting of 'Shidareguwa' mulberry. Similar result was found in the PGR-free rooting medium of $O$. grandiflora (Figs. 3A, 3B, 4E); and it could be due to the presence of enough endogenous auxin in the plantlets that stimulates root formation without exogenous auxin supplement [26]. However, the culture medium supplemented with $\mathrm{GA}_{3}$ increased rooting percentages, in this sense,
$0.5 \mathrm{mg} \cdot \mathrm{L}^{-1}$ and $0.75 \mathrm{mg} \cdot \mathrm{L}^{-1}$ at 90 days induced $60 \%$ of rooting compared with $45 \%$ of PGRs-free culture medium (Figs. $3 \mathrm{~A}$ and $4 \mathrm{E}$ ). Likewise, similar results were found for the length of main roots, where 0.75 and $1.0 \mathrm{mg} \cdot \mathrm{L}^{-1} \mathrm{GA}_{3}$ at 90 days showed the best results with $25-28 \mathrm{~mm}$, followed by PGRs-free culture medium with $18 \mathrm{~mm}$ (Fig. $3 \mathrm{~B}$ ). Furthermore, the use of $\mathrm{GA}_{3}$ has shown positive influence on the aerial plant length, where $0.50,0.75$ and $1.0 \mathrm{mg} \cdot \mathrm{L}^{-1} \mathrm{GA}_{3}$ at 90 days were the best treatments with more vigorous plants, of $54-57 \mathrm{~mm}$ (Figs. 3C and 4E). Zang et al. [27] found that $\mathrm{GA}_{3}$ improved the root system of rabbiteye blueberry (Vaccinium ashei), probably because gibberellins promote plant growth by stimulating photosynthesis, increasing levels of photosynthetic pigments, area and 


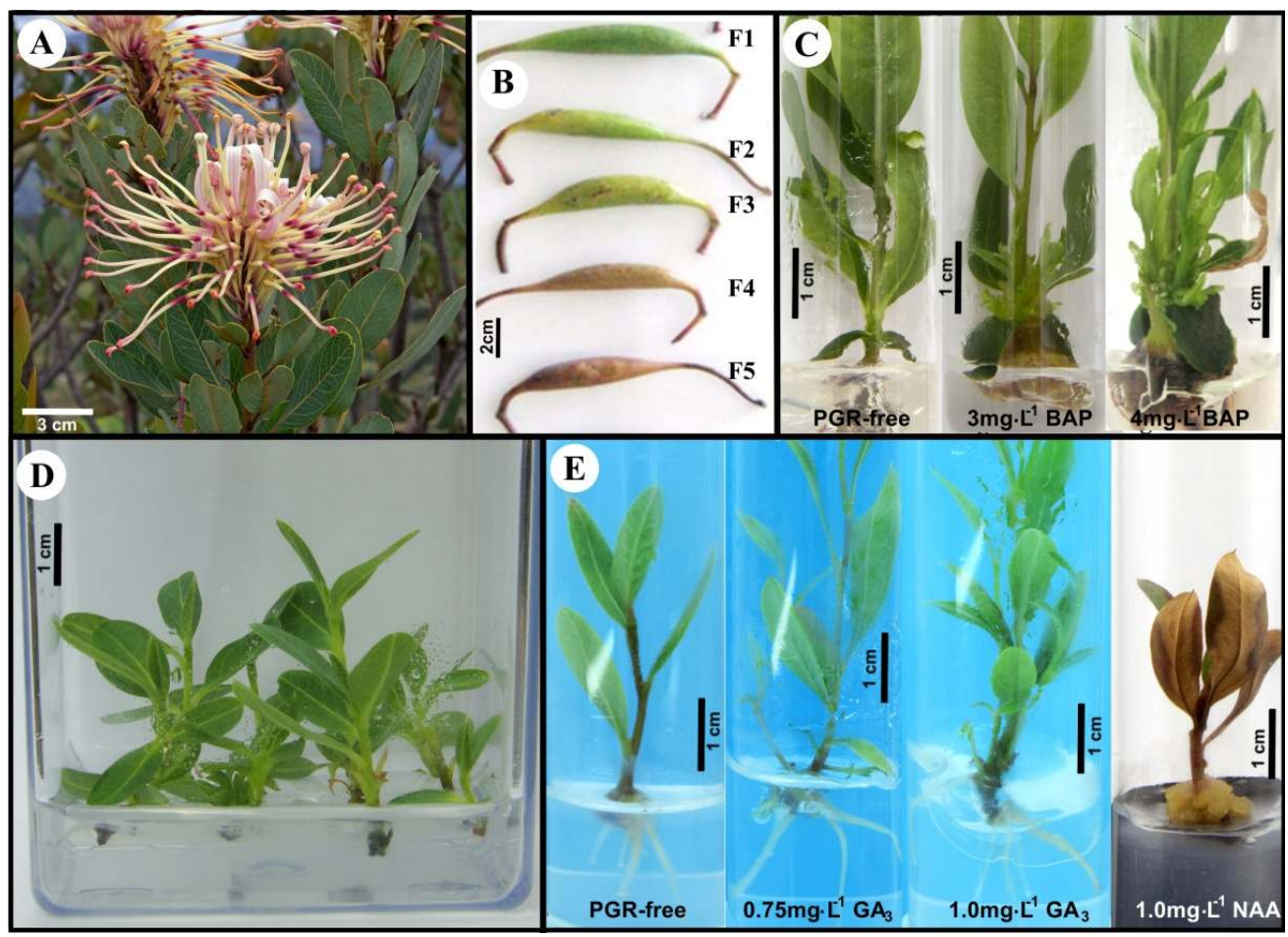

Fig.4. Plant material and micropropagation stages of Oreocallis grandiflora (Lam.) R. Br. A. Plant in its natural environment; $B$. Follicles used to evaluate seed germination: green (F1), yellow (F2), reddish-yellow (F3), red (F4) and brown (F5); C. Shooting at 60 days; D. Shoots establishment on PGR-free MS $1 \frac{1}{2}$ culture medium; E. Rooting at 90 days

weight of fresh and dry leaf $[27,28,29]$. Similarly, $\mathrm{GA}_{3}$ plays a role on the interlayer meristem near the base of internode, inducing plant elongation $[26,30]$.

Thus, the use of exogenous $\mathrm{GA}_{3}$ in the rooting culture medium of $O$. grandiflora increased shoot size, rooting percentage, and root length. Then, our results have improved rooting and microshoot quality, that are important properties for acclimatization and survival of plantlets from in vitro tissue culture [31]. In this sense, preliminary acclimatization of in vitro seedlings of $O$. grandiflora was performed using natural and low-cost substrates (sterile sand, peat and moss, alone or in combinations), and it was found that probably the best substrate for the survival and growth of $O$. grandiflora in greenhouse conditions was peat-sand (1:1), during the first 30 days in chamber humidity the survival percentage was $100 \%$, but when moisture decreased this percentage decreased down to $46 \%$ at 90 days, these results suggest that acclimatization needs more studies considering the investigation of possible soil microbial association such as mention Reynel and Marcelo [2].
The main stages of the in vitro micropropagation of $O$. grandiflora are represented in the Fig. 4.

\section{CONCLUSION}

Currently, biotechnological techniques contribute to the conservation, domestication and rational use of medicinal plant species. In that sense, micropropagation of $O$. grandiflora has shown us that 3.0 and $4.0 \mathrm{mg} \cdot \mathrm{L}^{-1}$ BAP were suitable for shoot formation; auxin promote callusing; and rooting is possible without supplement of exogenous plant growth regulators. However, the addition of $\mathrm{GA}_{3}$ improves rooting percentage, root and aerial plant length. Finally, the results obtained here provide important information for in vitro propagation of $O$. grandiflora, but the methodology is susceptible to improvements.

\section{ACKNOWLEDGEMENTS}

The authors are grateful of PhD. Mónica Arakaki, who revised and corrected the English grammar in the draft manuscript. Likewise, the experimental part of this research had financial 
support of the Dirección General de Investigación (DGI), of the Universidad Nacional Santiago Antúnez de Mayolo (UNASAM), Peru.

\section{COMPETING INTERESTS}

Authors have declared that no competing interests exist.

\section{REFERENCES}

1. Pretell J, Ocaña D, Jon R, Barahona E. Notes on some forest species of the Peruvian Sierra. FAO / Netherlands / INFOR project. Lima, Perú; 1985.

2. Brako L, Zarucchi J. Catalogue of the Flowering Plants and Gymnosperms of Peru. Missouri Botanical Garden, St Louis, USA; 1993.

3. Reynel C, Marcelo J. Trees of the Andean forest ecosystems, Manual of species identification. Series 9, Investigation and systematization. Regional program ECOBONA-intercooperation, Lima, Peru; 2009.

4. Soukup J. Vocabulary of the common names of the Peruvian flora and catalogue of the genera. Editorial Salesiana, Lima, Peru; 1987.

5. Monigatti M, Bussmann RW, Weckerle CS. Medicinal plant use in two Andean communities located at different altitudes in the Bolivar Province, Peru. J. Ethnopharmacol. 2013;145:450-464.

DOI: 10.1016/j.jep.2012.10.066

6. Gonzales De La Cruz M, Balden Malpartida S, Beltran Santiago H, Jullian V, Bourdy G. Hot and cold: Medicinal plant uses in Quechua speaking communities in the high Andes (Callejón de Huaylas, Ancash, Peru). J. Ethnopharmacol. 2014; 155:1093-1117.

DOI: 10.1016/j.jep.2014.06.042

7. Alejandro-Espinosa $M$, Jaramillo-Fierro $X$, Ojeda-Riascos S, Malagón-Aviles $\mathrm{O}$, Ramírez-Robles J. Antioxidant and antihyperglycemic activity of the medicinal species Oreocallis grandiflora (Lam.) R. Br., South of Ecuador. Bol. Latinoam. and Caribbean Plants Med. Aromat. 2013;12: 59-68.

8. Aroonpong P, Chang JC. Micropropagation of a difficult-to-root weeping mulberry (Morus alba var. shidareguwa): A popular variety for ornamental purposes. Sci. Hortic. (Amsterdam). 2015;194:320-326. DOI: 10.1016/j.scienta.2015.08.019
9. Dobránszki J, Teixeira da Silva JA. Micropropagation of apple - A review. Biotechnol. Adv. 2010;28:462-488. DOI: 10.1016/j.biotechadv.2010.02.008

10. Kumar V, Rout S, Tak MK, Deepak KR, Env N, Tech P. Application of biotechnology in forestry: Current status and future perspective. Nature Environment and Pollution Technology. 2015;14(3):645-663.

11. Lema-Rumińska J, Kulus D. Induction of somatic embryogenesis in Astrophytum asterias (Zucc.) Lem. in the aspect of light conditions and auxin 2,4-D concentrations. Acta Scientia. Pol., Hort. Cult. 2012;11(4): 77-87.

12. Pinna MS, Mattana E, Cañadas EM, Bacchetta G. Effects of pre-treatments and temperature on seed viability and germination of Juniperus macrocarpa Sm. Comptes Rendus - Biol. 2014;337:338344.

DOI: 10.1016/j.crvi.2014.03.001

13. Plíhalová L, Vylilová H, Doleal K, Zahajská L, Zatloukal M, Strnad M. Synthesis of aromatic cytokinins for plant biotechnology. N. Biotechnol. 2016;33:614-624.

DOI: 10.1016/j.nbt.2015.11.009

14. Müller D, Leyser O. Auxin , cytokinin and the control of shoot branching. 2011; 1203-1212.

Available:https://doi.org/10.1093/aob/mcr0 $\underline{69}$

15. Kieber JJ, Schaller GE. Cytokinins. Arabidopsis Book. 2014;12:e0168.

Available:https://doi.org/10.1199/tab.0168

16. Wang J, Tian C, Zhang C, Shi B, Cao X, Zhang T. Cytokinin Signaling Activates WUSCHEL Expression during Axillary Meristem Initiation; 2017.

Available:https://doi.org/10.1105/tpc.16.00 $\underline{579}$

17. Brenner WG, Ramireddy E, Heyl A, Schmülling T. Gene regulation by cytokinin in Arabidopsis. 2012;3:1-22.

Available:https://doi.org/10.3389/fpls.2012. $\underline{00008}$

18. Kushwah S, Laxmi A. The interaction between glucose and cytokinin signal transduction pathway in Arabidopsis thaliana. 2014;235-253.

Available:https://doi.org/10.1111/pce.1214 $\underline{9}$ 
19. Hiregoudar LV, Murthy HN, Hema BP, Hahn EJ, Paek KY. Multiple shoot induction and plant regeneration of Feronia limonia (L.) Swingle. Sci. Hortic. (Amsterdam). 2003;98:357-364.

DOI: 10.1016/S0304-4238(03)00018-9

20. Nagori $\mathrm{R}$, Purohit SD. In vitro plantlet regeneration in Annona squamosa through direct shoot bud differentiation on hypocotyl segments. Sci. Hortic. (Amsterdam). 2004;99:89-98.

DOI: $10.1016 / S 0304-4238(03) 00084-0$

21. Porfírio S, Gomes da Silva MDR, Cabrita MJ, Azadi P, Peixe A. Reviewing current knowledge on olive (Olea europaea L.) adventitious root formation. Sci. Hortic. (Amsterdam). 2016;198:207226.

DOI: 10.1016/j.scienta.2015.11.034

22. Su Y, Liu Y, Zhang X. Auxin - Cytokinin Interaction Regulates Meristem Development. 2011;4(4). Available:https://doi.org/10.1093/mp/ssr00 $\underline{7}$

23. Kareem A, Roy MV, Radhakrishnan D, Sugimoto K, Sondhi Y, Aiyaz M, Prasad K. De novo assembly of plant body plan: A step ahead of Deadpool, Regeneration. 2016;3:182-197.

Available:https://doi.org/10.1002/reg2.68

24. Marín JA. The micropropagation and the improvement of fruit species. Academy of Exact, Physical, Chemical and Natural Sciences, Zaragoza, Spain; 1997.

25. Olmos S, Luciani G, Galdeano E. Micropropagation. In: Levitus G, Echenique V, Rubinstein C, Hopp E and Mroginski L (Eds.) Biotechnology and plant breeding II. Ediciones INTA, Buenos Aires. 2010;353-362.

26. Taiz L, Zeiger E. Plant Physiology: Volume I. Universitat Jaume I, Valencia, Spain; 2006.

27. Zang YX, Chun IJ, Zhang LL, Hong SB, Zheng WW, Xu K. Effect of gibberellic acid application on plant growth attributes, return bloom, and fruit quality of rabbiteye blueberry. Sci. Hortic. (Amsterdam). 2016; 200:13-18.

DOI: 10.1016/j.scienta.2015.12.057 27

28. Bose SK, Yadav RK, Mishra S, Sangwan RS, Singh AK, Mishra B, Srivastava AK, Sangwan NS. Effect of gibberellic acid and calliterpenone on plant growth attributes, trichomes, essential oil biosynthesis and pathway gene expression in differential manner in Mentha arvensis L. Plant Physiol. Biochem. 2013;66:150-158.

DOI: 10.1016/j.plaphy.2013.02.011

29. Masood A, Khan MIR, Fatma M, Asgher M, Per TS, Khan NA. Involvement of ethylene in gibberellic acid-induced sulfur assimilation, photosynthetic responses, and alleviation of cadmium stress in mustard. Plant Physiol. Biochem. 2016; 104:1-10.

DOI: 10.1016/j.plaphy.2016.03.017

30. Pierik RL. In vitro cultivation of the superior plants. Ediciones Mundi-Prensa, Madrid, Spain; 1990.

31. Aina OO, Quesenberry $\mathrm{KH}$, Gallo $\mathrm{M}$. Culture vessel and auxin treatments affect in vitro rooting and ex vitro survival of six Arachis paraguariensis genotypes. Sci. Hortic. (Amsterdam). 2015;183:167-171. DOI: $10.1016 /$ j.scienta.2014.12.006

(c) 2017 Olivera-Gonzales et al.; This is an Open Access article distributed under the terms of the Creative Commons Attribution License (http://creativecommons.org/licenses/by/4.0), which permits unrestricted use, distribution, and reproduction in any medium, provided the original work is properly cited.

Peer-review history:

The peer review history for this paper can be accessed here: http://sciencedomain.org/review-history/19936 